\title{
From the Problem of Ground Water Salinity towards Sustainable Prosperity in Agricultural Sector in Coastal Region of Gujarat, India
}

\author{
Niraj Kathrani ${ }^{1}$, Anurag Kandya ${ }^{1}$, Iris Koekkoek ${ }^{2}$, Tess Op Den Kelder ${ }^{3}$, Purvesh Rajpurohit ${ }^{4}$ \\ ${ }^{1}$ Pandit Deendayal Petroleum University \\ Gandhinagar, Gujarat, India \\ niraj.kmten16@sot.pdpu.ac.in; akandya@gmail.com \\ ${ }^{2}$ Utrecht University \\ The Netherlands \\ iriskoekkoek@gmail.com \\ ${ }^{3}$ Stockholm University \\ Sweden \\ tessopdenkelder@hotmail.com \\ ${ }^{4}$ Silver Oak College of Engineering \\ India \\ rajpurohitpurvesh1995@gmail.com
}

\section{Extended Abstract}

Salinity is one of the severe environmental factors limiting the productivity of agricultural sector. The mixing of saltwater with freshwater even in small quantities renders groundwater unsuitable for agricultural use [1]. The extension of seawater intrusion into coastal aquifers is a dynamic and interconnected phenomenon that depends on various factors such as recharge, coastal topography and groundwater abstraction from coastal aquifers [2][3]. Most of the crop plants are sensitive to the high concentration of salts in the soil. Some soils are naturally high in salinity but most salinity problems on farms are increased by farm practices.

India has a dynamic coastline of about $7500 \mathrm{~km}$ length, including the mainland coastline of about $5400 \mathrm{~km}$. Nearly 25 $\%$ of the total population of India resides in the coastal tracts of the country. The state of Gujarat has the longest coastline of $1600 \mathrm{~km}$, which is about one-third of the total coastline of India. In coastal areas of Gujarat, due to the heavy withdrawal of ground water and very less recharge sources (only rainfall), ingress of sea water has converted the available ground water resources into a saline belt. Currently $12 \%$ of the coastal land area is saline, as appose to a global average of $7 \%$. The salinity ingress is around $0.5-1.0 \mathrm{~km}$ per year as the ground water is receding by $3-5 \mathrm{~m}$ per year. The salinity has adversely affected the agricultural productivity of this area with few studies stating the reduction to be as high as $62 \%$ in few areas of Coastal Gujarat. About $88 \%$ of the total available water resources are used for irrigation. Therefore, agriculture sector can be seen as the biggest cause of the groundwater salinization [4].

As per the Gujarat Costal Salinity Prevention Cell report 2014, witnessing the declining agricultural productivity of the coastal areas of Gujarat, West India which has around 1500 villages. The present study has been undertaken to revisit the effect of salinity on agricultural productivity and model the current scenario of ground water uptake and ingress of salinity viz.-a-viz. the agricultural productivity along with various futuristic scenarios and finally suggest a framework for moving from 'ground water salinity' towards 'sustainable prosperity' in the agriculture sector. This framework revolves around 4 major objectives which are 1) the bottom-up approach of educating and strengthening the local bodies regarding the ground water usage, 2) change in mechanism of subsidy, 3) introducing the concept of 'Green Farmer' and its benefits and 4) awareness regarding low water intensive crops and the strategies for popularizing them including that of food festivals.

\section{References}


[1] H. Abd-Elhamid, A. Javadi, "A cost-effective method to control seawater intrusion in coastal aquifers, " Water Resour. Manag., vol. 25, pp. 2755-2780, 2011.

[2] G. H. P. Oude-Essink, E. S. van Baaren, P. G. B. de Louw, "Effects of climate change on coastal groundwater systems: a modeling study in the Netherlands," Water Resour. Res., vol. 46, W00F04, 2010.

[3] G. Ferguson, T. Gleeson, "Vulnerability of coastal aquifers to groundwater use and climate change," Nat. Clim. Chang., vol. 2, pp. 342-345, 2012.

[4] Evolve sustainable approaches for prevention and mitigation of salinity ingress, whilst enhancing livelihood resilience of communities affected by salinity in coastal villages of Gujarat, Coastal salinity prevention cell, 2014. 